\title{
Characterization of Rhizobacteria for Multiple Plant Growth Promoting Traits from Mung Bean Rhizosphere
}

\author{
Soumya Routray $^{1 *}$ and Veena Khanna ${ }^{2}$ \\ ${ }^{1}$ Department of Microbiology, PAU, Ludhiana, Punjab-141004, India \\ ${ }^{2}$ Department of Plant Breeding and Genetics, PAU, Ludhiana, Punjab-141004, India \\ *Corresponding author
}

\section{A B S T R A C T}

Keywords

IAA, GA,

Flavonoid, Mung

bean, PGP,

Rhizobacteria,

Rhizobium

Article Info

Accepted:

16 December 2017

Available Online:

10 January 2018
Soil microorganisms, that flourish in, on or around plant rhizosphere, have tremendous potential to stimulate plant growth by plethora of mechanisms. In this study, 40 rhizobacterial isolates from 15 mung bean rhizospheric soil samples were morphologically and biochemically analysed and tentatively assumed to belong to genera Bacillus (35\%), Pseudomonas (55\%) and Rhizobium (10\%). Ten isolates were evaluated of plant growth promoting (PGP) traits at $35^{\circ} \mathrm{C}$ viz. production of IAA, GA (Gibberellic acid), flavonoid and siderophore as well as $\mathrm{Zn}$ and $\mathrm{P}$ solubilisation. Our study showed that all the 10 isolates produce IAA, GA and flavonoid in the range of $6.06-32.13 \mu \mathrm{g} / \mathrm{ml}, 109.8-126.3$ $\mu \mathrm{g} / \mathrm{ml}$ and $68.9-224.7 \mu \mathrm{g} / \mathrm{ml}$ respectively, whereas only 7 isolates were found to be efficient producers of both hydroxamate and catecholate siderophores in the range of 342.8-732.7 $\mu \mathrm{g} / \mathrm{ml}$. Again, all these isolates were potent solubiliser of $\mathrm{Zn}$ and $\mathrm{P}$ in plate assay. The solubilisation indices ranged from 2.1 to $4.4,1.4$ to 6.0 and 1.8 to 3.1 for $\mathrm{ZnO}$, $\mathrm{ZnCO}_{3}$ and tri-calcium phosphate respectively. From this study, 3 isolates; S1P1, S4P1 and S13P1 showing superior PGP traits can be executed as effective biofertilizer in field trials for mung bean production.

\section{Introduction}

Among the dozen of pulses, mung bean is the third important pulse crop cultivated in India and accounts for $65 \%$ of acreage and $54 \%$ of the world's production (Gowda et al., 2015). It is consumed as whole grain or as dal and valued for its high quality protein that constitutes about 24-25\% of total nutrients in seed (Singh, 2010). It is cultivated as sole or inter crop for grain or green manure. Being a leguminous crop, mung bean has the ability to establish a symbiotic relationship with its compatible microsymbiont Rhizobium, setting up of biological nitrogen fixation (BNF) in the root nodules and supply the plant's needs for nitrogen (Mandal et al., 2009). This Rhizobium-legume symbiosis is the most important plant-bacterial interaction observed in legumes and can fix as much as $30-74 \mathrm{~kg}$ $\mathrm{N} /$ ha. This legume-Rhizobium interaction is of considerable agricultural importance; it leads to greater quantitative enhancement of combined $\mathrm{N}$ in soil thus, reduces the cost of fertilizer for farmers who grow legumes (Dudeja and Duhan, 2005). Besides 
Rhizobium several other rhizospheric microbes play key role in ecosystem functioning by controlling bio-geochemical nutrient cycles, supplying available nitrogen and phosphorous to plants (Kirk et al., 2004). These soil microbes are termed as plant growth promoting rhizobacteria (PGPRs). In recent years, PGPRs have received worldwide importance. Their ability for high rhizospheric competence, tolerance to biotic and abiotic stresses, mass multiplication, broad spectrum action for plant growth promotion, compatibility with other rhizobacteria, environmental safety and excellent control and reliability make them very useful in maintaining sustainability in agriculture (Jeyrajan and Nakkeeran, 2000).

Study and analysis of their potential for plant growth promotion is very crucial. In this study 10 rhizobacterial isolates were evaluated in vitro for their ability to synthesize IAA, Gibberllic acid (GA), flavonoids and siderophore, their potential for solubilisation of minerals; $\mathrm{P}$ and $\mathrm{Zn}$ was also tested.

\section{Materials and Methods}

\section{Isolation of rhizobacteria}

For isolation of rhizobacteria; the basic procedure of serial dilution and pour plate technique were used. Three different media; nutrient agar, king's B medium (King et al., 1954) and YEMA medium were used to isolate Bacillus, Pseudomonas and Rhizobium respectively at $35^{\circ} \mathrm{C}$.

\section{Biochemical rhizobacteria}

\section{characterization}

of

Biochemical characterization of the isolated rhizobacteria was done on the basis of catalase production, methyl red test, nitrate reduction, starch hydrolysis and gram reaction (Holt et al., 1994).

\section{IAA and GA production}

Characterization of rhizobacterial isolates for IAA and GA production was done as per the methods given by Gordon and Weber (1951) and Borrow et al., (1955) respectively.

\section{Flavonoid production}

Total flavonoid content was estimated by aluminium chloride method proposed by Zhishen et al., (1999) using naringenin as standard. The absorbance was measured at $510 \mathrm{~nm}$.

\section{Zn solubilisation}

In vitro solubilisation of $\mathrm{ZnO}$ and $\mathrm{ZnCO}_{3}$ by rhizobacteria was determined in plate assay method given by Fasim et al., (2002) and Zinc solubilisation index (S.I.) was calculated as per the formula of Ramesh et al., (2014).

\section{Plate assay for phousphorous solubilisation}

Cultures were spot inoculated on Pikovskaya's agar plates and incubated at $35^{\circ} \mathrm{C}$. The zone of clearance was recorded at $7^{\text {th }}$ day after inoculation. $\mathrm{P}$ solubilisation index (S.I.) was calculated as per the formula of Ramesh et al., (2014).

\section{Production of siderophore}

Detection of hydroxamate and cateholate type of siderophore was done as per the methods given by Snow (1954) and Neilands (1981) respectively.

\section{Results and Discussion}

\section{Isolation and characterization of rhizobacteria}

A total of 40 rhizobacterial isolates were obtained from 15 different mung bean 
rhizospheric soil samples collected from different parts of Punjab. Out of these, 35\% isolates formed on nutrient agar medium, showed white to off-white coloration with round to spherical colony morphology, 55\% isolates obtained from Kings B medium of which 9 isolates produced characteristic yellowish-green colouration and $10 \%$ isolates on Congo-red YEMA medium, showed characteristic round, gummy, white to translucent colony morphology. On the basis of cultural, morphological and biochemical characteristics these isolates were tentatively assumed to be Bacillus, Pseudomonas and Rhizobium (Table 1).

\section{IAA production}

Indole-acetic-acid (IAA) being the major and most abundant auxin in plants, plays a key role in plant growth regulation and development. Many PGPRs have the ability to produce IAA equivalents and remarkably affect the plant growth by altering the endogenous level of auxin synthesized in plants. In the present work, 10 rhizobacterial isolates were evaluated for their ability to synthesize IAA at $35^{\circ} \mathrm{C}$ (Table 2).

A significant variation in IAA production by these isolates has been recorded that ranged from $1.94-15.71 \mu \mathrm{g} / \mathrm{ml}$ and 6.06-32.13 $\mu \mathrm{g} / \mathrm{ml}$ in Trp- and Trp+ medium respectively. The isolates S10B1 $(15.71 \mu \mathrm{g} / \mathrm{ml})$ and S1P1 (32.13 $\mu \mathrm{g} / \mathrm{ml})$ were the best IAA producers in Trpand Trp+ medium respectively.

\section{GA production}

Gibberellins are the class of phytohormones that are commonly associated with modification of plant morphology. They are reported to stimulate stem elongation, flower and fruit development, breaking dormancy and seed germination. Kaur and khanna (2017) isolated $5 \mathrm{GA}$ producer rhizobacteria that showed higher GA production at $30^{\circ} \mathrm{C}$ as well as $40^{\circ} \mathrm{C}$. In the following study 10 rhizobacterial isolates were tested for their ability to produce $\mathrm{GA}$ at $35^{\circ} \mathrm{C}$. Isolate $\mathrm{S} 1 \mathrm{P} 1$ $(126.3 \mu \mathrm{g} / \mathrm{ml})$ was found to be most efficient GA producer followed by SR1 $(121.1 \mu \mathrm{g} / \mathrm{ml})$ and S4P1 $(118.6 \mu \mathrm{g} / \mathrm{ml})$. The GA production by these 10 isolate ranged from 109.8-126.3 $\mu \mathrm{g} / \mathrm{ml}$ (Table 2).

\section{Production of flavonoid}

Flavonoids are documented to be the most important signalling molecules associated with plant-microbe interactions. Flavonoid production is an important plant growth promoting trait exhibited by many soil microbes that not only help in colonization in rhizosphere but also enhance nodulation by inducing nod gene. In the present study 10 rhizobacterial isolates were screened and their abilty for flavonoid production was evaluated in vitro (Table 2). The study revealed that isolate S13P1 $(224.7 \mu \mathrm{g} / \mathrm{ml})$ recorded with maximum flavonoid followed by S4P1 (197.5 $\mu \mathrm{g} / \mathrm{ml})$. Khan et al., (2017) isolated 15 different strains of flavonoid and auxin producing rhizobacteria from the rhizosphere of Medicago sativa $\mathrm{L}$.

\section{Production of siderophore}

Iron is an important micronutrient essential for bacterial metabolism. The bacteria inhabiting in soil acquire iron by secreting low-molecular weight iron chelators; siderophores which have high association constants for complexing iron. Rajkumar et al., (2010) reported that siderophore producing bacteria directly enhance the plant growth by supplementing iron requirement of the host plant as well as inhibit the growth of phytopathogens in rhizosphere. In the following study, 7 rhizobacterial isolates exhibited the ability of siderphore production (Table 2). 
Table.1 Cultural, morphological and biochemical characteristics of rhizobacterial isolates

\begin{tabular}{|l|l|l|l|} 
Characteristics & Bacillus sp. & Rhizobium sp. & Pseudomonas sp. \\
\hline Gram's reaction & +ve & -ve & -ve \\
\hline Shape & Rods & Rods & Rods \\
\hline Pigment & - & + & + \\
\hline Pigment colour & White & Whitish pink & Fluorescent green \\
\hline Starch hydrolysis & + & + & + \\
\hline Catalase production & + & + & + \\
\hline Methyl red test & - & - & - \\
\hline Nitrate reduction & + & + & + \\
\hline Characteristics & Bacillus sp. & Rhizobium sp. & Pseudomonas sp. \\
\hline
\end{tabular}

Table.2 IAA, Gibberellic acid, flavonoid and siderophore (hydroxamate and chatechol type) production at $35^{\circ} \mathrm{C}$

\begin{tabular}{|c|c|c|c|c|c|c|}
\hline \multirow{2}{*}{$\begin{array}{c}\text { Rhizobacterial } \\
\text { isolates }\end{array}$} & \multicolumn{2}{|c|}{ LAA-equivalent $(\mu \mathrm{Hg} / \mathrm{ml})$} & $\begin{array}{c}\text { GA } \\
\text { production } \\
(\mu \mathrm{g} / \mathrm{ml})\end{array}$ & $\begin{array}{c}\text { Flavonoid } \\
\text { production } \\
(\mu \mathrm{\mu g} / \mathrm{ml})\end{array}$ & $\begin{array}{c}\text { hydroxymate } \\
\text { type }\end{array}$ & $\begin{array}{c}\text { Catechol } \\
\text { type } \\
(\mu \mathrm{g} / \mathrm{ml})\end{array}$ \\
\hline S1P1 & 11.88 & 32.13 & 126.3 & 170.1 & ++ & 677.0 \\
\hline S4P1 & 5.97 & 10.38 & 118.6 & 197.5 & + & 441.9 \\
\hline S4P5 & 9.11 & 15.43 & 113.5 & 114.9 & + & 430.4 \\
\hline S10B1 & 15.71 & 22.05 & 116.8 & 135.2 & - & - \\
\hline S12P4 & 8.31 & 12.13 & 111.3 & 101.9 & + & 465.1 \\
\hline S12P6 & 5.93 & 7.42 & 110.2 & 116.7 & ++ & 493.7 \\
\hline S13P1 & 10.65 & 16.93 & 117.6 & 224.7 & + & 732.7 \\
\hline S13P4 & 1.94 & 6.06 & 109.8 & 166.3 & + & 342.8 \\
\hline SR1 & 9.92 & 28.77 & 121.1 & 147.7 & - & - \\
\hline SR3 & 13.40 & 21.24 & 114.4 & 68.9 & - & - \\
\hline
\end{tabular}

Table. $3 \mathrm{ZnO}, \mathrm{ZnCO}_{3}$ and phosphate solubilisation index by rhizobacterial isolates at $35^{\circ} \mathrm{C}$

\begin{tabular}{|c|c|c|c|}
\hline \multirow{2}{*}{ Isolates } & \multicolumn{3}{|c|}{ Solubilisation Index (S.I.) } \\
\hline S1P1 & ZnO & $\mathbf{Z n C O}_{\mathbf{3}}$ & $\mathbf{P}$ \\
\hline S4P1 & 3.8 & 2.6 & 3.1 \\
\hline S4P5 & 4.4 & 6.0 & 2.6 \\
\hline S10B1 & 2.6 & 2.1 & 1.8 \\
\hline S12P4 & 2.8 & 2.0 & 2.1 \\
\hline S12P6 & 3.1 & 2.7 & 1.9 \\
\hline S13P1 & 2.8 & 2.0 & 1.8 \\
\hline S13P4 & 3.5 & 2.4 & 3.0 \\
\hline SR1 & 2.4 & 1.4 & 2.4 \\
\hline SR3 & 2.1 & 2.0 & 2.3 \\
\hline
\end{tabular}


These isolates showed positive test for production of both hydroxamate and chatecholate type siderophores of which S13P1 $(732.7 \mu \mathrm{g} / \mathrm{ml})$ followed by S1P1 $(677.0 \mu \mathrm{g} / \mathrm{ml})$ found to be the best catecholate siderophore producers whereas higher hydroxamate production was observed in S1P1 and S12P6.

\section{Solubilisation of $\mathbf{Z n}$}

Zinc is an essential nutrient for plant growth and mainly found in the form of $\mathrm{ZnS}$ (sphalerite), zincite $(\mathrm{ZnO})$, smithsonite $\left(\mathrm{ZnCO}_{3}\right)$ zinkosite $\left(\mathrm{ZnSO}_{4}\right)$, franklinite $\left(\mathrm{ZnFe}_{2} \mathrm{O}_{4}\right)$ etc. (Hafeez et al., 2013). It is also evident that, inoculation of potent strains of $\mathrm{Zn}$ solubiliser rhizobacteria increases the yield of field crops such as wheat, rice, maize and barley.

In this study 10 rhizobacterial isolates were screened for their ability to solubilise $\mathrm{ZnO}$ and $\mathrm{ZnCO}_{3}$ in the plate assay. Among all the rhizobacterial isolates; S4P1 showed maximum solubilisation index of 4.4 and 6.0 for $\mathrm{ZnO}$ and $\mathrm{ZnCO}_{3}$ respectively. However, the range of 2.1 to 4.4 for $\mathrm{ZnO}$ and 2.0 to 6.6 for $\mathrm{ZnCO}_{3}$ solubilisation was recorded from the isolates (Table 3).

\section{Phosphate solubilisation}

Microorganisms enhance the $\mathrm{P}$ availability to plants (Chen et al., 2006). It seems probable that plant growth substances produced by PSBs (phosphate solubilising bacteria) improve plant growth by their direct effects on metabolic processes. However, they induce proliferation of lateral roots and root hairs resulting in increased nutrient absorbing surfaces leading to greater nutrient absorption (Shahab et al., 2009). Among the 40 rhizobacterial isolates only 10 isolates were able to solubilise tri-calcium phosphate in vitro with maximum solubilisation index of
3.1 recorded from isolate $\mathrm{S} 1 \mathrm{P} 1$. Whereas the range for $\mathrm{P}$ solubilisation was recorded to be 1.9 to 3.1 (Table 3 ).

The present study revealed that soil microorganisms exhibit several plant growth promoting traits that could directly influence plant growth and development affecting its yield. In our study the isolate S1P1 showed maximum production of IAA $(32.13 \mu \mathrm{g} / \mathrm{ml})$, GA $(126.3 \mu \mathrm{g} / \mathrm{ml})$ and showed maximum $\mathrm{P}$ solubilization index of 3.1 whereas, isolate S13P1 was found to be the best flavonoid $(224.7 \mu \mathrm{g} / \mathrm{ml})$ and siderophore $(732.7 \mu \mathrm{g} / \mathrm{ml})$ producer again isolate S4P1 was maximally recorded with $\mathrm{ZnO}$ (4.4) and $\mathrm{ZnCO}_{3}$ (6.0) solubilization indices. Considering all the above parameters the isolates $\mathrm{S} 1 \mathrm{P} 1, \mathrm{~S} 4 \mathrm{P} 1$ and S13P1 were found to be most feasible for use as bio-inoculants alone or in combination with Rhizobium in mung bean cultivation.

\section{References}

Borrow, A., Brain, P.W., Chester, V.E., Curtis, P.J., Hemming, H.G., Henehan, C., Jeffereys, E.G., Lloyd, P.B., Nixon, I.S., Norris, G.L.F. and Radley, M., 1955. Gibberellic acids a metabolic product of the fungus Gibberella fujikuroi some observations on its production and isolation. J Sci Food Agri. 6, 340-48.

Chen, Y.P., Rekha, P.D., Arun, A.B., Shen, F.T., Lai, W.A. and Young, C.C., 2006. Phosphate solubilizing bacteria from subtropical soil and their tricalcium phosphate solubilizing abilities. Appl Soil Ecol, 34, 33-41

Dudeja, S.S. and Duhan, J.S., 2005. Biological nitrogen fixation research in pulses with special reference to mung bean and urd bean. Indian Pulses Res, 18:107-18.

Fasim, F., Ahmed, N., Parsons, R., Gadd, G.M., 2002. Solubilization of zinc salts by bacterium isolated by the air environment of tannery. FEMS Microb Lett, 213: 1-6.

Gordon, A.S. and Weber, R.P., 1951. Calorimetric estimation of Indole acetic acid. Pl Physiol, 25, 192-95. 
Gowda, C.L.L., Chaturvedi, S.K., Gaur, P.M., Kumar, C.V.S. and Jukanti, A.K., 2015. Pulses research and development strategies for India. India pulses handbook, pp. 40-47.

Hafeez, F.Y., Abaid-Ullah, M. and Hassan, M.N., 2013. Plant growth gromoting rhizobacteria as Zinc mobilisers: A promising approach for cereals biofortification.

Holt, J.G.N., Krieg, R., Sneath, P.H.A., Stanley, J.T. and Williams, S.T., 1994. Bergey's manual of determinative bacteriology, $9^{\text {th }}$ ed. The Williams and Wikins Co. (Lippincoli, Williams and Wikins), Baltimore.

Jeyarajan, R. and Nakkeeran, S., 2000. Exploitation of microorganisms and viruses as biocontrol agents for crop disease management. Biocontrol Potential and their Exploitation in Sustainable agriculture Kluwer Academic Publishers, USA, pp. 95116.

Kaur, G. and Khanna, V., 2017. Evaluation of thermotolerant rhizobacteria for multiple plant growth promoting traits from pigeonpea rhizosphere. Journal of Applied and Natural Science, 9 (2): 920 - 923

Khan, I., Hussain, A., Ud Din, I., Sayyed, A., Husna, Zeb, A. and Hamayun, M., 2017. Indole acetic acid and flavonoids production by rhizospheric bacteria isolated from Medicago sativa L. Rhizosphere. Int J Biosci, 10, 19-26.

King, E.O., Ward, M.K. and Raney, D.E., 1954. Two simple media for the demonstration of pyocyanin and fluorecein. $\mathrm{J} \mathrm{Lab} \mathrm{Clin} \mathrm{Med,}$ 44, 301-07.

Kirk, J.L., Beaudette, L.A., Hart, M., Moutoglis, P., Klironomous, J.N., Lee, H. and Trevors, J.T. 2004. Methods of studying soil microbial diversity. J Microbiol Methods, $58,169-88$.
Maheshwari et al., (eds.), Bacteria in Agrobiology: Crop Productivity, pp: 21735.

Mandal, S., Mandal, M. and Das, A., 2009. Stimulation of indole acetic acid production in a rhizobium isolate of Vigna mungo by root nodule phenolic acids. Arch Microbiol, 191: 389-93.

Neilands, J. B., 1981. Iron absorption and transport in microorganisms. Annu Rev Nutr, 1, 27-46.

Rajkumar, M., Ae, N., Prasad, M.N.V. and Freitas, H. 2010. Potential of siderophoreproducing bacteria for improving heavy metal phytoextraction. Trends Biotechnol, 28, 142-49.

Ramesh, A., Sharma, S.K., Sharma, M.P., Yadav, N. and Joshi, O.P., 2014. Inoculation of zinc solubilizing Bacillus aryabhattai strains for improved growth, mobilization and biofortification of zinc in soyabean and wheat cultivated in versitols of central India. Appl Soil Ecol, 73, 87-96.

Shahab, S., Ahmed, N. and Khan, N.S., 2009. Indole acetic acid production and enhanced plant growth promotion by indigenous PSBs. African J Agric Res, 4, 1312-16.

Singh, R.P., 2010. Comparative analysis: Area, production and yield of major pulse crops growing states in India. Status paper on pulses, pp.3-8.

Snow, G.A., 1954. Mycobactin, a growth factor for Mycobacterium johnei: II. Degradation and identification of fragments. $\mathrm{J}$ Chem Soc, 49:2588-96.

Zhishen, J., Mengcheng, T., and Jianming, W., 1999. The determination of flavonoid contents in mulberry and their scavenging effects on superoxide radicals. Food Chem, 64: 555-59.

\section{How to cite this article:}

Soumya Routray and Veena Khanna. 2018. Characterization of Rhizobacteria for Multiple Plant Growth Promoting Traits from Mung Bean Rhizosphere. Int.J.Curr.Microbiol.App.Sci. 7(01): 2264-2269. doi: https://doi.org/10.20546/ijcmas.2018.701.274 